\title{
Rhetorical Museology
}

Museología Retórica

\section{Elizabeth Weiser}

\section{(2) OpenEdition}

\section{Journals}

Electronic version

URL: http://journals.openedition.org/iss/2254

DOI: 10.4000/iss.2254

ISSN: 2306-4161

\section{Publisher}

ICOM - International Council of Museums

\section{Printed version}

Date of publication: 1 August 2020

Number of pages: 207-221

ISBN: 978-2-491997-11-3

ISSN: 2309-1290

\section{Electronic reference}

M. Elizabeth Weiser, «Rhetorical Museology », ICOFOM Study Series [Online], 48-1 | 2020, Online since 01 August 2020, connection on 08 August 2020. URL : http://journals.openedition.org/iss/2254 ; DOI : https://doi.org/10.4000/iss.2254 


\section{Rhetorical Museology}

\section{Elizabeth Weiser \\ The Ohio State University, Columbus, Ohio, US}

A BSTRACT

A rhetorical lens can bring a new dynamic and new insights to museological studies of our "multicultural platforms for negotiations" because the focus of rhetoric is on the close reading of how to persuasively operate collectively in the public sphere. In a world that grows increasingly polyphonic, museums are often the only public institution presenting the kind of discourse that aims to build a dialectical community across diverse groups. Thus, the increased interest of rhetoricians in their work. The question of museology's role becomes in rhetorical terms, "What are the theories and analyses that explain how museums impact the world?" This article examines several rhetorical themes, including the public sphere, rhetorical appeals, epideixis, the rhetorical triangle, polyphony, juxtaposition, the tragic and the comic frames, and, of course, persuasion.

Keywords: museology, rhetoric, polyphony, persuasion, Jenny Holzer, Kenneth Burke

\section{RESUMEN}

\section{Museología Retórica}

Una lente retórica puede aportar una nueva dinámica y nuevas ideas a los estudios museológicos de nuestras "plataformas multiculturales para negociaciones" porque el enfoque de la retórica está en porque el enfoque de la retórica está en la lectura atenta de cómo operar persuasivamente colectivamente en la esfera pública. En un mundo que se vuelve cada vez más polifónico, los museos son a menudo la única institución pública que presenta el tipo de discurso que tiene como 
objetivo construir una comunidad dialéctica en diversos grupos. De ahí el creciente interés de los retóricos en su trabajo. La cuestión del papel de la museología se convierte en términos retóricos: "¿Cuáles son las teorías y los análisis que explican cómo los museos impactan en el mundo?" Este artículo examina varios temas retóricos, incluida la esfera pública, los pisteis retóricos, la epideixis, el triángulo retórico, la polifonía, la yuxtaposición, los marcos trágico y cómico y, por supuesto,

la persuasión.

Palabras clave: museología, retórica, polifonía, persuasión, Jenny Holzer, Kenneth Burke

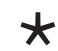

\section{Introduction}

This past autumn my university's art museum, the Wexner Center for the Arts, hosted an exhibit of Jenny Holzer's work as part an exhibit of Ohio artists. While Holzer continues to be a prolific and provocative artist today, she is perhaps best known for some of her very first works, the Inflammatory Essays and Truisms, and it is these that covered the walls of the Wexner galleries. Holzer's Inflammatory Essays are "composed precisely of Ioo words in 20 lines containing statements influenced by an assortment of provocative ideologies [and] manifestos" (Wexner, 2019, p. 7), and her Truisms are "250 single-sentence declarations [that]...bring together a wide range of conflicting theoretical, philosophical, and political positions" (Guggenheim Bilbao, 2019). You may be familiar with some portion of either of these works ("Abuse of power comes as no surprise," "don't talk down to me...i'll cut the smile off your face") without being aware that they are part of a larger artistic series - or even that they are art at all. The point, though, is that these highly polemical works are meant to be viewed not as individual statements but as a polyphonic, conflicting collection. Here is one Inflammatory Essay telling us to "destroy superabundance, starve the flesh, shave the hair, expose the bone" while the one next to it counsels that "you might as well stay drunk or shoot junk or be a crazy fucker." Which of these should we believe? Which does Holzer want us to believe? As she herself said in an interview, "Alone, some of them would be completely irresponsible" (Cohen, 1990, p. 157).

And yet visitors have consistently sought out the statements they most identify with, or bought the merchandise with one or another statement, by itself, as most representative of their own worldview. That we want to read Holzer's work from one viewpoint (our own) while it is persistently exhibited, in museums around the world, from another viewpoint (that of a polyphony of juxtaposed voices) speaks to the theme of this article: To be relevant in our world, museums 
have become "multicultural platforms for negotiations" (Smeds, 2019) between individual and individual, and between individual and museum-a stance that is emotionally difficult for many of us in the modern world. The new museum sees its mission not as the distribution of knowledge but as the production of a sociopolitical effect in its at-times resisting community, and new museologists, in turn, study these effects of museums on the world.

I argue in this essay that a rhetorical lens can bring a new dynamic and new insights to these studies, because the focus of rhetoric is on what it means to be a public and how individuals are persuaded to operate collectively in the public sphere. As I explain it in my recent book Museum Rhetoric:

A rhetorical lens might consider how the British Museum's stance of 'disinterested holder of the world's treasures' shapes and reflects a particular public identity, and then how individual Britons are invited to assume that identity themselves. The mantel of that identity is significantly different from the one shaped and reflected by [the metaphor of] 'America's attic' at the National Museum of American History, or from the sense engendered by entering 'the King's treasury' at the Thai National Museum. Each of these perspectives brings forth a different sense of one's role in one's society - more or less hierarchical or populist, more or less beholder or beholden - and therefore it engenders a different range of responses as one embraces, modifies, or resists the identity offered. (2017, pp. 8-9)

99

The question of museology's role viz. museums, then, becomes in rhetorical terms "What are the theories and analyses that explain how museums impact the world?" These questions have been raised by cultural studies theorists as well, of course, and rhetoric has embraced cultural critiques over the past several decades. As Thomas Rostek noted in his collection on their intersections, both are fields

aiming to reveal the relationship between expressive forms and the social order; [working within] discursive practices [and] how ideas are caused to materialize in texts; both concerned with how these structures are actually effective at the point of consumption; and both interested in grasping such textual practices as forms of power and performance. $(1998$, p. 2)

99

What rhetoric contributes to this relationship, then, is first, the analytical entry point that museums exist primarily to persuade rather than explain, 
and that they are persuading their audience toward greater civic engagement by encouraging that audience to identify with particular narratives. Second, rhetoric provides what Blake Scott calls

its rich storehouse of theory for analyzing the production and reception of texts, its utility in unpacking the frames, lines, appeals, and ideological underpinnings of arguments, and its careful attention to language and deep engagement with specific texts. (2003, pp. 364-65)

\section{Public Sphere and Public Memory}

Rhetoric has a 2500-year history of studying human discourse and its effects. That rhetorical history is built around the discourse of the public sphere. In recent decades, as they turned from pure textual analysis to materiality, rhetoricians have examined first the discourse of nationalism, then the discourse surrounding public memorials, and, most recently, the discourse within museums. Hauser's Vernacular Voices: The Rhetoric of Publics and Public Spheres (1999) analyzed dialogue in key communal spaces; Clark's Rhetorical Landscapes in America (2004) examined the preparation required to turn public spaces into persuasive encounters; Haskins' (2015) Popular Memories considered extramuseal participatory forms of commemoration and their effect on the development of democratic citizenship. Meanwhile Blair, Jeppeson, and Pucci's 1991 analysis of the Vietnam Memorial opened up the field to public memory studies, work that has been continued in Dickinson, Blair, and Ott's Places of Public Memory (2010), which examines the materiality of memory in both museums and memorial sites, Phillips' Global Memoryscapes (20I0), which expands that analysis to the world, my own Museum Rhetoric: Building Civic Identity in National Spaces (2017), which explores nation-building in national heritage museums, or the Center of the West examinations of Dickinson, Ott, and Aoki.

Meanwhile, notions of the public sphere are evident in scholars writing in ICOFOM's Defining Museums of the $21^{\text {st }}$ Century (see for instance Escudero), in many of those scholars collected in its Politics and Poetics of Museology, and in Olga Zabalueva's work in the recent The Future of Tradition in Museology: Materials for a Discussion, among others.

Museums and their study matter to rhetoricians because in a world that is more diverse than anything classical rhetoric could have imagined, museums are often the only public institution presenting the kind of discourse that builds a dialectical community. As I discuss in Museum Rhetoric:

Interpreting the social world within a rhetorical narrative framework...a museum layers onto the social realm a national 
life story that proposes a flexible unification of diverse pasts. That museum narrative of unified social diversity, in turn, works rhetorically to invite each individual to identify his or her own personal life story with the collective story. This is not merely the psychological identity work that museum studies scholars have examined previously. Instead, rhetorical museology allows us to see historical social narratives and individual identity work as the warp and weft of an interwoven identification process with always evolving communal values invoking memory made manifest in material space.

(Weiser, 2017, p. 6)

\section{9}

Recent museology has considered the importance of the visitor, including the 20I2 ICOFOM symposium "The Special Visitor" and the subsequent collection by Davis and Smeds, Visiting the Visitor: An Enquiry into the Visitor Business in Museums (2016). The focus on "visitor," however, often seems to necessarily obviate the importance of "object" and "collection," which can be rendered nearly invisible. After all, as Steven Conn (2010) wrote, Do Museums Still Need Objects?

This dichotomy between visitor and object is clear in a textual analysis of the new definition of the museum proposed by ICOM to its General Assembly in Kyoto in 2019. Instead of the "permanent institution" which "acquires, conserves, researches, communicates, and exhibits the tangible and intangible heritage," the museum becomes the "democratising...space" that works to "collect, preserve, research, interpret, exhibit, and enhance understandings" (ICOM, 2019). Visitor understandings, that is, not material heritage. As the visitor (and their understanding) ascends in importance, the thing (cultural heritage) recedes. So are museums for heritage, and therefore museology should embrace the interpretation of things, or are museums for visitors, and therefore museology should embrace the understanding of people? Rhetoric allows us to answer "yes" to both because its close analysis of object is always in service to the suasory effect on audience.

A close analysis of the argument of the symbol (text/ object/event) and the symbol-producer (rhetor/speaker/writer/curator), then, sees them always in a dance with the symbol-receiver (audience/reader/visitor) -see Fig. I-whose material conditions and histories present both the exigencies to be addressed and the constraints within which the response must operate, or avoid, or counter. The role of a student of rhetorical museology, then, would be to study what form of dance is produced, and to what effect. Below I will discuss several of what could be many rhetorical approaches taken. 


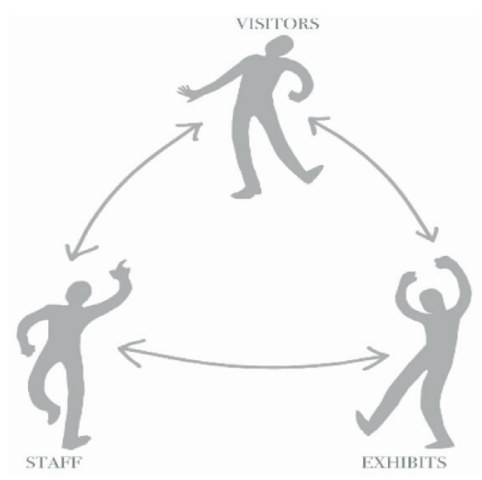

\section{Epideixis}

As Aristotle would see it, museums are rhetorically a form of epideictic persuasion. They do not deal solely with debates for future action (that is the deliberative rhetoric of the parliament) nor solely with past facts (that is the forensic rhetoric of law courts). Instead, as epideictic arguments, heritage museums are "both reminding [the audience] of the past and projecting the course of the future" (Aristotle, I99I, I358b) by upholding the values that guide a community to certain actions. The old epideictic systems of Aristotle's day-public speeches, pageants-are too monolithic for our diverse communities; not everyone is convinced by the master narrative. Individuals today share space with people who seem so different from themselves that the concept of unified civic space, much less shared stories, meanings, and values, is hard to grasp. This can lead to intolerance and the hegemonic need to tell others what to believe/how to behave-or it can lead to alienation, the anomie of modern cultural enclaves, separate and rarely interacting. Neither of these lead to fruitful argumentation. Museums as epideictic spaces can bridge the gap between these poles, as spaces that both hold common beliefs together ("cultural glue") and help a community envision new possibilities ("cultural goad"). Through a presentation of past deeds that openly reaffirms present values and urges future action in line with those values, museums work to persuade individual visitors to embrace what the community collectively considers ideal (see also Nina Robbins in this volume).

Why praise communal values? To motivate people toward responsible civic engagement. "To praise a man is in one respect akin to urging a course of action," as Aristotle noted ( $1367 \mathrm{~b})$. Here rhetoric reminds us that the dispassionate presentation of reason, logos, does not breed a motivation for unity without the affective attachment of emotion, pathos, given weight by the authority, ethos, of the institution. Without some sense of the benefit of common values there is little impetus to find common ground - and the starting point for common values lies more in emotional resonance than factual truth. For this 
reason, Chaim Perelman and Lucie Olbrechts-Tyteca argued that epideictic oratory "strengthens the disposition toward action by increasing adherence to the values it lauds" (I969/I99I, p. 50) and therefore persuades people to create a desired future.

The challenge for people who want to evoke change is thus not to avoid pathos, emotion, but to channel that emotion away from jingoistic opposability into an exploration, and celebration, of mutually held values which serve as the starting point for dialogue. This is where the ethos authority of the museum setting can play a particularly strong role.

We can see the desire for epideictic relevance rather than forensic fact-presentation in Héctor Valverde Martínez's recent call to ICOFOM for a new museum paradigm responding to a "changing society": "In Latin America was born another concept of the Museum, as a place of social dynamism, an epicenter of social transformation; however, [this concept] was ephemeral" (2019, p. 165). He lamented that originally modern museums had turned into "odes to the past" that cannot "link themselves to their immediate community of practice" (p. I66) even as they attempt to reach out. That outreach, though, merely continues their monolithic expository role as they seek through technology to "transmit' their contents 'to help' people 'understand"' their exhibits (p. I67). Rhetoric's understanding of the power of epideixis provides a theory for why, if they are to become agents of social transformation, museums must occupy their role in the public sphere less as experts and more as inspirations.

The ICOM proposed museum definition, then, marking museums as "inclusive and polyphonic spaces for critical dialogue about the pasts and the futures," while it is problematically aspirational as a pragmatic definition, does seek to recognize that epideictic role in public engagement. It is an educational role that is less about the transmission of contents and more of a social partnership, an egalitarian, active means of persuasion as a mutual undertaking. As Bruno Brulon Soares pointed out in the $42^{\text {nd }}$ ICOFOM symposium, Brazilian educator Paolo Freire's globally influential action-reflection praxis and view of education not as a banking model of depositing knowledge but as the mutual development of critical consciousness points toward a different kind of heuristic process (Brulon Soares, 2019). Education that functions not merely to convey the "meaning" of objects nor to advocate some clear-cut partisan stance can serve as rhetorical education that invites critical reflection and increased adherence to desired values. It is ironic, therefore, that the educational function of museums is left out of the proposed ICOM definition - perhaps what is needed is a redefinition of museum education as a Freirean social partnership leading to new engagement with civic action.

I. Translations from Spanish of Valverde are mine. 


\section{Polyphonic Juxtaposition}

I believe that museums, alone amongst public institutions, have a unique way of persuading audiences toward collective engagement. Through polyphonic juxtaposition they bring multiple voices into dialogue and debate within a unifying framework.

As an example, I recently visited the US National Parks Service's exhibit at the Minuteman Missile National Historic Site outside Philip, South Dakota. It exhibits the intercontinental ballistic missiles used during the U.S.-U.S.S.R. Cold War - missiles that "[hold] the power to destroy civilization, but [are] meant as a nuclear deterrent to maintain peace and prevent war" ("Minuteman Missile," 2019). Which truth do you believe to be true: destruction or deterrence? The visitor book made it clear that passionate people from many sides of the debate around the world visited the museum. How to engage them beyond their personal silos of preconceived ideas? Convincing people who sincerely hold partisan beliefs to consider other views means more than presenting facts and telling visitors that they're either naïve or bloodthirsty. The Minuteman Missile museum encourages dialogue and debate by identifying a mutual fear of all sides - global annihilation - and allowing juxtaposed voices, of deterrence and destruction, from both the U.S. and U.S.S.R to present their arguments. At the same time, the exhibit confronts the visitor with the repeated question, "What would you have done?" At the end, it narrates first the multiple instances where missiles were mistakenly almost fired, and second the fact that thousands of missiles remain. As concluding statements, these are appeals to pathos - a sobering reminder of our unifying fear of mutual annihilation that turns the exhibit's question from pondering what we would have done into the values-driven "What should we do, now and for the future?"

Which brings me back to Jenny Holzer and the commonplaces with which she infuses her work. Some of her Truisms, and even some of her Inflammatory Essays, no doubt speak strongly to our own experiences and values, while others do not. In isolation, they are just another example of the current divisive political discussions filling our airwaves and halls of government. But in the museum, they are not meant to be experienced individually. Jostling against each other, juxtaposing each other, they invite us to slow down and think more deeply about the ways that arguments continually rely on what we take for granted, the lenses through which we subconsciously view our world. Their very abundance in Holzer's work - dozens of Essays, hundreds of Truisms - should also remind us that those lenses are different for each person, and so it is no surprise that others' perspectives, the way they view and name their world, are also different from ours.

The web guide for Holzer's Guggenheim Bilbao retrospective last summer includes Holzer's reflection that, placed in a museum, her work (which was originally plastered individually on the streets of New York City) takes on added layers of meaning: 
With a sign or a poster in the street you have the space of time it takes a person to walk a few feet...I offer what will work in seconds... There are sentences that are complete messages, that you can absorb in an instant, but, if someone wants to stay longer, there's an entire series in which these three-second lines are embedded that gets more complicated. (Guggenheim Bilbao, 2019)

\section{9}

This embedded complication, the juxtaposition of diverse voices that forces the visitor to ponder alternatives, is what I believe as a rhetorician is the unique discourse tool of museums hoping to engage their visitors in greater civic awareness and action.

Modern rhetorical theory was born from the realization that even strongly held and vociferously debated facts were not enough to convince people to change their worldview: they must be persuaded. In the social upheavals following "the war to end all wars" and subsequent global economic crisis of the early $2 \mathrm{O}^{\text {th }}$ century, partisans of both the Right and the Left lamented that the masses did not change their views after having "the truth" explained to them. They did not act in their own best interests. Foundational rhetorician Kenneth Burke recognized that the first step to persuasion lay in convincing people that their own perspective was not the one truth but one among many possibilities. This realization could only occur when their subconscious ideas and beliefs-their commonplaces-were laid bare and then, as Nietzsche wrote, "put...together ironically, forging the alien, separating the familiar" (I992, p. 639) so that new connections could be made, new perspectives entertained. He called this "perspective by incongruity" (1937/1984, p. 308).

Such are Holzer's installations, but these destabilizing effects to produce new ways of thinking occur throughout the museum world. For instance, Henrik Lübker's depiction of the Hans Christian Andersen Museum in Odense, Denmark, describes a "house of fairytales" in which "one of the most important principles...has been to stage the fundamental tensions and ambiguities of the fairytales instead of providing an authoritarian interpretation of them" (2019, p. II5). These ambiguities are inherent in the fairytales themselves, Lübker argues, but this unease is often erased in our minds, replaced by the more comforting, anodyne memory of childhood tales. That is not, however, what is in Andersen's texts, nor what is now in the museum itself. Incorporation of new audio technology "allows the museum to create a world in which a multitude of voices are present, just as it is in Andersen's fairytales. Objects come alive and speak, offering often contrasting perspectives to the narrated voice of Andersen-each claiming a truth. As such, the museum gives credence to the idea of polyphony rather than singular authoritarian communication" (p. II6). This is Burke's perspective by incongruity in material action. 


\section{Polyphonic self-Identity}

A museum exhibit can serve as an aesthetic model for how to curate the real-world turn from opposing viewpoints to dialogue.

Such juxtaposed polyphony can be uncomfortable because it goes against the social desire for a forensic truth, a secure singular fact. When Holzer first posted her Inflammatory Essays on walls around New York City in 1977, nightly news anchor Walter Cronkite, often cited as "the most trusted man in America," was still ending his broadcasts by telling viewers, "And that's the way it is." Holzer's Essays were, at the time, a protest against this type of hegemonic neutrality. Today, listening to the political and cultural debates carried out vociferously over the internet, in authoritarian rallies, and in mass movement protests, not to mention in war, it is easy to long for more neutral language, to wonder if all public discourse has not in fact become an inflammatory essay. Yet Burke insisted that neutrality was not how human language worked, that "neutrality" was a refusal to deal with the language of everyday life, full of inducement and exhortation. Rhetorical theory suggests that if all the world sounds today like a series of Inflammatory Essays, perhaps that is because more voices are participating in the conversation. We all speak in contradictory Truisms and Inflammatory Essays because that is what a diverse group of humans do. What we are still learning is how to not obscure their attendant passions but turn their power from pure opposition to dialogue and polyphonic communal aspiration.

A museum exhibit can serve as one model for this turn. Any musealization of polyphony is not a mere reflection of its world; it is reality curated, carefully selected to fit its audience just as Holzer chose which of her Inflammatory Essays to display and which to set aside in the space/time of Ohio in 2019, which to place next to which and which to give greater prominence in the particular space of the gallery. Every exhibit, in making these same decisions, is forging novel connections, demonstrating unities both new and long-standing. By staging the parameters of what brings the collective together, museums are better able than most institutions today to give space as well to what divides us. Museums can present ambiguous perspectives that disrupt the customary and highlight what is deflected from the story being constructed as well as what is reflected in that story. As communication scholar Željka Miklošević argues in a recent article:

All those involved in the making of meanings need to question themselves about what sorts of meaning they shape and for whom, what modes and media best convey or help form those meanings, what is 
the power of these meanings for certain groups of people and whether they need to be counterbalanced, revised and reshaped. (2019, 130)

Her depiction of the critical consciousness of communication sciences is an instance of the power of combining the close symbolic analysis of rhetorical discourse studies with the social power analyses of cultural studies.

Admittedly, asking visitors to consider not only multiple viewpoints but also multiple emotional stances is asking much of them. As Peter Aronsson and Simon Knell have pointed out in their study of European national museums, visitors resist the idea that they are being confronted with polyphony and being persuaded to reforge their identity in a museum visit. "They did not visit with the intention of developing, understanding or crystallising their national identities. They believed these museums were about history, not identity" (2012, p. 28). Visitors want to view the museum narratives as "truth" - and with polyphony they are being asked not only to reflect on the idea of social truths, partially constructed by themselves, but also on divergent truths, partially constructed by others.

Museal polyphony asks the visitor to reverse, or at least examine, a process that psychologists describe as an essential step in our identity formation: unifying disparate parts of our "selves" diachronically and synchronically. To create a self out of our memories, we unite the different roles we play in life (diachronic unity) and the different choices we have made over the years (synchronic unity) into one "story of me" (McAdams, 2003, pp. I88-89). Communities, I argue in Museum Rhetoric, do the same to forge the story of their community or nation (Weiser, 2017, pp. 43-44). Polyphony asks us to break apart that comforting self-identity and remember the divisions that make up the unity: that the hand is also composed of five fingers.

This is where the curated ethos of the museum is particularly important. By the force of its ethos, a museum defines an overarching unified space ("this is the museum of Hans Christian Anderson or the museum of the Chinese nation"); it reminds visitors of those aspects of the narrative that they share ("we all fear mutual annihilation," "we are all Kiwis"); and it does so in an institution that visitors trust to tell historic truth. Because of this general unity, the museum provides the psychological space to safely explore divisions: like a Holzer exhibit, it can curate a juxtaposed polyphony of narratives in dialogue with each other, pointing out each other's flaws and filling in each other's gaps - inviting visitors, in other words, to reflect critically, reforge divisions, and contribute new voices. This kind of engagement, so difficult in the real world of forensic blaming and deliberative angst, is easier in a space overtly designed to engage with the epideictic values of its society. 
In simple terms, people enter a museum to learn, which is not how we enter the other arenas of our public life, and therefore the arguments presented can persuade toward mutual engagement in the reforging of the narrative rather than the win-lose stance of so much other public argument.

This is, in a nutshell, also the purpose of rhetoric in society: to unite in identification with others while allowing for division from them. Without identification with the other, there is no motivation to persuade - you are an outsider, we are not the same community - and so we fall into anomie. But without division, there is equally no motivation to persuade, as you must surely think as I do (and if not, you must be forced to bend to my will). Engaged interaction is the opposite of these mutual misunderstandings.

\section{The tragic and the comic frame}

When we cannot comprehend the motives of the opposition, when we see their actions as simply foreign or wrong, then we are seeing the world through what Burke called the tragic frame, a dangerous narrative in which one side is seen as all good and the other all evil. It is the classic fairytale, but also the classic propaganda of two nations at odds. This could have been - but is not - the frame of the Minuteman Missile museum discussed earlier. Instead, it chose what Burke conceived of as the comic frame:

Human enlightenment can go no further than in picturing people not as vicious, but as mistaken. When you add that people are necessarily mistaken, that all people are exposed to situations in which they must act as fools, that every insight contains its own special kind of blindness, you complete the comic circle, returning again to the lesson of humility that underlies great tragedy. $(1937 / 1984, p .41)$

In the comic frame, where everyone's perspective is necessarily limited, then opponents are not evil but tragically mistaken people who are blind to their own blindness, and whom we might help to view events through a wider frame. But humility is also necessary to recognize that our own perspective, right as it seems, is also limited. We are also fools, blind to our blindnesses. In Freirean terms, we have no real authority to engage in banking education, presenting our own one-sided perspective as the Truth rather than seeking mutual dialogue. We are back to the rhetorical dance with our audience, mutually examining the subject - say, a particular worldview in an exhibit - within a critical pedagogy that allows the audience space to interpret while allowing museum staff to curate multiple perspectives and highlight the caesuras of uninvoked voices that may lead to new insights, new actions. 
I am reminded of a special exhibit in the Nordiska Museet in Stockholm, Sweden, in 20r2, on the indigenous Sámi people of the far North. The exhibit included a carved wooden seidi, a sacramental object that would have been placed at a special or sacrificial site, and which had been removed from its original location by museum collectors a century earlier. Displayed with the seidi were comments from a Sámi "exhibition reference group" that both explained and critiqued the exhibit. They read, "Who assumed the right to desecrate the Sámi's sacred places? I hold them in great respect and would never think of removing anything. 'A seidi unquestionably raises issues of morality, ethics and questions of repatriation and preservation." These were critical words for the museum, juxtaposed alongside the seidi itself - which yet remained enclosed in its vitrine. The museum neither acknowledged nor denied the seidi's sacred status, leaving visitors to question their own unstated perspectives on what should be piously worshipped and what should be piously musealized.

Viewed from the tragic frame, one of the actors in the seidi debate (Nordiska or Sámi) is always right - morally right - and the other is wrong, stupid or evil. Viewed from a comic frame, the only tragedy is the potential for blindness on both sides, and thus there is room for continued engagement and mutual persuasion. I think of similar debates between museums and indigenous peoples across the Americas, and the negotiated displays and repatriations that are resulting. As Burke wrote in a letter to a friend, "Ideally all the various voices are partisan rhetoricians whose partial voices 'competitively cooperate' to form the position of the dialogue as a whole" (Fogarty, 1959, p. 326). Analyzing both the nature of this debate and the means by which each voice works to persuade the visitor through narrative, argument, artifact, and spatial rhetorics can bring new insights to bear on these increasingly relevant public spaces.

\section{Persuading people to ponder}

As Marion Bertin recently writes, the task of representing heritage in a world of differential power structures is a complex process of integrating and unifying, exhibiting and representing. She quotes Ramsay, who notes that "in a multi-ethnic society, to try to affirm multiple identities within one national institution makes of the museum a politically contested space," and she adds, "History, particularly colonial history, is just as difficult to represent" (2019, p. 24). ${ }^{\mathrm{I}}$ As I have been arguing here, one rhetorical solution is to acknowledge those divisions, to embrace the multiple voices as necessarily partial, mutually blind and in need of each other. Such an approach asks visitors to think about values rather than demanding their allegiance to programs. One-sided assertions only convince those who already believe them, and so in rhetorical terms they persuade no one. What is more persuasive is asking people to think about alternatives, and this kind of theorizing of possibilities is the particular contribution of the ethos of museum space.

I. Translation from French of Bertin is mine. 
A review of Holzer's Bilbao retrospective summed up the exhibit by noting: "[T]he exhibition seemed to have an effect on those who've managed to see it. On the days I visited, visitors were noticeably more serious and reflective than typical museumgoers" (Kapplow 2019). Museology can study, and activist museology can encourage, the methods that promote such reflection. A cultural rhetorical approach can provide a toolkit of theoretical frameworks for how an object, exhibit, or museum persuades, defines, or constructs its audience and how the diverse components of that audience, in turn, influence the museum. Finally, the hybridity of cultural rhetorical approaches can reinforce museological perspectives that refuse to be fixed or homogeneous, instead juxtaposing their own polyphony of methodologies to best understand the museal world.

\section{References}

Aristotle. (199I). Rhetoric. Translated by George A. Kennedy. New York: Oxford University Press.

Aronsson, P., \& Knell, S. (Eds.) (20I2). European National Museums Making Histories in a Diverse Europe. Linköping: Linköping University Electronic Press.

Bertin, M. (2019). Décoloniser les Musée du Pacifique: Quelque Défis pour le Futur. In Smeds, K. (Ed.), The Future of Tradition in Museology: Materials for a Discussion (pp. 22-26). Paris: ICOFOM.

Scott, J.B. (2003). Extending Rhetorical-Cultural Analysis: Transformations of Home HIV Testing. College English 65 (4), pp. 349-367.

Brulon Soares, B. (2019). Cultural Action for Museums in Action: Geneology of a Concept in Experimental Practices and Theories. ICOFOM 42nd Symposium. Talk presented at 2019 ICOFOM Symposium, Kyoto, Japan.

Burke, K. (1937/1984). Attitudes toward History. Berkeley: University of California Press.

Cohen, S. (1990). An Interview with Jenny Holzer. Columbia: A Journal of Literature and Art, I5, I49-I59.

Fogarty, D. (1959). Kenneth Burke's Theory. In Roots for a New Rhetoric (pp. 56-87). New York: Bureau of Publications, Teachers College, Columbia University.

Guggenheim Bilbao. (2019). Jenny Holzer: Thing Indescribable. Retrieved October 27, 2019, from https://jennyholzer.guggenheim-bilbao.eus/en/exhibition.

International Council of Museums. (2019). Museum Definition. ICOM Activities. Retrieved October 27, 2019, from https://icom.museum/en/activities/ standards-guidelines/museum-definition/. 
Kapplow, H. (2019, August 29). Jenny Holzer Hits Her Mark in a Major, Largely Unnoticed Retrospective. Hyperallergic. Retrieved September Io, 2019 from https://hyperallergic.com/515025/jenny-holzer-things-indescribable-guggenheim-museum-bilbao/.

Lübker, H. (2019). Searching for a Posthuman Ecology of Representation. In K. Smeds (Ed.), The Future of Tradition in Museology: Materials for a Discussion (pp. II4-II8). Paris: ICOFOM.

McAdams, D. (2003). Identity and the Life Story. In R. Fivush \& C. Haden (Eds.), Autobiographical Memory and the Construction of a Narrative Self: Developmental and Cultural Perspectives (pp. I87-207). Mahwah, NJ: Lawrence Erlbaum.

Miklošević, Ž. (2019). Reflexive Communication as a Methodology of Museology. In K. Smeds (Ed.), The Future of Tradition in Museology: Materials for a Discussion (pp. I29-132). Paris: ICOFOM.

Nietzsche, F. (1873/1992). Truth and Falsity in an Ultramoral Sense. Trans. Maximilian A. Mügge. Rpt. in H. Adams (Ed.), Critical Theory since Plato (pp. 634-39). Fort Worth, TX: Harcourt Brace Jovanovich.

Perelman, C., \& Olbrechts-Tyteca, L. (1969/199I). The New Rhetoric: A Treatise on Argumentation. South Bend: University of Notre Dame Press.

Rostek, T. (Ed.) (1998). At the Intersection: Cultural Studies and Rhetorical Studies. New York: Guildford Press.

Smeds, K. (2019). The Future of Tradition in Museology: Call for Publication and Participation. Retrieved March I5, 2019, from http://network.icom. museum/-icofom/meetings/next-conference/.

U.S. National Park Service. (2019). Minuteman Missile: Hidden in Plain Sight. Minuteman Missile. Retrieved October 27, 2019, from https://www.nps. gov/-mimi/index.htm.

Valverde Martínez, H. (2019). El Mito del Museo Moderno en las Sociedades del Siglo XXI. In K. Smeds (Ed.), The Future of Tradition in Museology: Materials for a Discussion (pp. I64-I68). Paris: ICOFOM.

Weiser, M.E. (20I7). Museum Rhetoric: Building Civic Identity in National Spaces. State College, PA: Penn State University Press.

Wexner Center for the Arts. (2019). Here: Ann Hamilton, Jenny Holzer, Maya Lin. Museum guide. Columbus, OH: Wexner Center for the Arts. 